\title{
Concept of cervical ectopy/Quruhal Rahim in Unani system of medicine: a review
}

\author{
Tooba Fahad ${ }^{1 *}$, Ismath Shameem²
}

\begin{abstract}
${ }^{1}$ Department of Amraze Niswan Wa Qabalat, Hayat Unani Medical College and Research Centre, Kakori, Lucknow, Uttar Pradesh, India

${ }^{2}$ Department of Ilmul Qabalat Wa Amraze Niswan, National Institute of Unani Medicine, Kottigepalya, Magadi Road, Bengaluru, Karnataka, India
\end{abstract}

Received: 21 March 2020

Revised: 22 June 2020

Accepted: 30 June 2020

\section{*Correspondence:}

Dr. Tooba Fahad,

E-mail: drtoobaf@gmail.com

Copyright: (c) the author(s), publisher and licensee Medip Academy. This is an open-access article distributed under the terms of the Creative Commons Attribution Non-Commercial License, which permits unrestricted non-commercial use, distribution, and reproduction in any medium, provided the original work is properly cited.

\begin{abstract}
Cervical ectopy is one of the commonest gynecological conditions seen in OPD's, about $80-85 \%$ of women suffer from cervical ectopy during their life time. Many a times, it is an accidental finding in an asymptomatic woman coming for routine gynecological examination. Although it is a benign lesion, but may predispose to complications like infertility, cervical intraepithelial neoplasm, risk of various sexually transmitted infections like C. trachomatis, N. gonorrhoea, human papilloma virus, human immunodeficiency virus, cytomegalovirus and shows malignant changes as it progresses. Ectopy occurs when the columnar epithelium lining the endocervix, extends onto the ectocervix. As the disease takes 10-20 years to progress from pre invasive to invasive disease, preventive measures such as screening and treatment modalities should be adopted. Early diagnosis of cervical ectopy is important for its effective management and for prevention of its long-term sequel. The treatment option available in conventional medicine includes surgical procedure either electro or, cryocautery, but have their own complications. Hence, this treatment is limited due to its complications and contraindications and need for safer alternate therapy. In Unani system of medicine, various formulations are available as treatment of quruhal rahim, which have been recommended to be used locally in the form of humool for immediate healing of wound, exhibiting the properties of anti-inflammatory (muhallile warm), desiccant (mujaffif), wound healing (mundamile qurooh), sedative (musakkin), antiseptic (dafa'e ta'ffun) etc. This review article gives a detailed description of cervical ectopy as mentioned in classical Unani text including its etiopathogenesis, clinical presentation and principles of treatment as well as evidence-based Unani medicine.
\end{abstract}

Keywords: Cervical ectopy, Humool, Quruhal rahim, Unani system of medicine

\section{INTRODUCTION}

Cervical ectopy is one of the commonest gynecological conditions seen in OPD's and $80-85 \%$ of women suffer from cervical ectopy during the reproductive age. ${ }^{1-6}$ Many a times, it is an accidental finding in an asymptomatic woman coming for routine gynecological examination. ${ }^{7-11}$ Though it is not fatal, but if left untreated may leads to infertility and predispose to cervical cancer, which is considered as frequent cancer among women in India. ${ }^{13}$ Pathologically, it is the replacement of the stratified squamous epithelium of the portiovaginalis by the columnar epithelium of the endocervix. ${ }^{12,14-17}$ Predisposing factors for cervical ectopy are early sexual life, multiple sexual partners, presence of STI's, lower genital tract infections, low socioeconomic status, poor personal hygiene, poor health awareness etc..$^{2,7,8,17-19}$ Etiology includes cervical trauma during delivery, 
abortion and sexual intercourse, use of contraception either barrier or steroidal etc. ${ }^{10,12,15,18}$ Although it is benign, but may be troublesome due to its chronicity and nature of recurrence. As the disease takes 10-20 years to progress from pre invasive to invasive disease, preventive measures such as screening and treatment modalities should be adopted. ${ }^{8}$ Thus, an early and accurate diagnosis of cervical ectopy is of paramount importance for its effective management and for prevention of its long-term sequel. ACOG recommend all sexually active women above the age of 18 years, should have an annual pap smear test and pelvic examination. The patient may present with symptoms like vaginal discharge, low backache, dyspareunia, intermenstrual bleeding, post coital bleeding, pelvic pain etc. ${ }^{1-3,6,11,14,16,20,23,25,26}$ The treatment option available in conventional medicine for cervical ectopy is surgical treatment like electro or cryocautery, which though effective, but have their own complications like cramping pain during procedure, copious discharge per vaginum, PID, risk of secondary hemorrhage, cervical stenosis, infertility etc. ${ }^{1,3,8,20}$ Hence, the need for alternate treatment arises which is to be safe, effective and free from side effects. In USM, several drugs are available for healing of cervical ectopy which can be used safely in humool form.

\section{Methodology}

Authentic ancient text of Unani medicine was searched to obtain the Unani concept of cervical ectopy. Pub Med/Google Scholar was also searched with the keywords; cervical ectopy, cervical erosion, food items as anti-cancerous, vaginal discharge; low back ache; ointment, Unani drugs having cytotoxic effects, alternative regimes for cervical ectopy, prevention of cervical cancer etc.

\section{Unani concept}

The description of cervical ectopy is similar to Quruhal Rahim or zakhm Wa Juruhe Rahim in classical Unani text. ${ }^{27-31}$ Qarha is an arabic word which means wound. ${ }^{32-}$ ${ }^{37}$ Ulcer is defined as breach in the continuity of epithelial membrane, or chronic loss of continuity in fleshy mass (Ibn Hubal). ${ }^{37-39}$ Majoosi in Kamilus Sana mentioned that ulcer is formed if Tafarruq-I-Ittisal (discontinuity) exists for longer duration. ${ }^{29}$ Hakim Azam Khan states that Qarha is actually caused by the rupture of an abscess. ${ }^{37}$ Ibn Sina mentioned that the three main types of Amraze Rahim are Sui Mizaj (altered temperament), Sui Tarkeeb (altered composition) and Amraze Mushtarik (combination of both). ${ }^{30}$ Further, he cited in Al Qanoon that three basic factors responsible to cause ulcer are: rupture of inflammatory swelling, sepsis in a wound, and corrosive pustules. ${ }^{40,41}$ Ibn Sina states that Quruhal Rahim may be clear, purulent or non-purulent, inflammatory or non-inflammatory, associated with or without cancrum and can occur within the uterus or other sites as well. ${ }^{30}$

\section{Etiopathogenesis}

It is caused by various external and internal factors.

External factors like wounds due to uterine injury either by direct trauma or instrumentation, drug induced i.e. local use of haad drugs in the form of humool or farzaja and Hikka Al-Rahim. ${ }^{27,42}$ Internal factors like difficult labour, mismanagement of labour, flow of acute yellow bile towards the uterus causing gradual erosion of cervix, rupture of inflammatory swelling or pustules. Seldom, it is congenital. ${ }^{27,31-34,42}$

\section{Clinical presentation}

Patient may present with intense pelvic pain if ulcer is on Fam-I-Rahim, abnormal vaginal discharge headache, pain in thighs (Buqrat), fever, excessive thirst. ${ }^{28,30,32-}$ $34,43,44$ On examination, Qarha on the cervix is visible on inspection and even palpated as rough area on bimanual examination. ${ }^{29,42}$

\section{Diagnosis}

It is based on history and clinical examination.

Oozing of fresh blood after trauma is indicative of uterine ulcer, which occurs due to rupture of epithelium..$^{33,34}$

If vaginal discharge is scanty, white, thick in consistency, slippery, without smell and pain is indicative of nonpurulent ulcer.

If vaginal discharge is blood stained, offensive, purulent associated with mild pain is indicative of purulent ulcer.

If vaginal discharge is black colored, offensive, associated with severe pain, fluctuation and prominent vessels, is indicative of akkala (cancrum). ${ }^{30,33,34}$

If vaginal discharge is associated with fever and chills and other sign and symptoms of inflammation is indicative of Waram Al-Rahim (PID).

If vaginal discharge is excessive in amount and resembles alcoholic sediments is indicative of rupture of an abscess. ${ }^{27-30,33}$

Vaginal discharge of Qarha Al-Rahim is purulent and associated with pain, while in Akkala Al-Rahim, the discharge is thick, offensive and black coloured. ${ }^{27}$

\section{Usoole ilaj}

\section{General measures}

The main aim in treatment of ulcer is to procure tajfif (desiccation) to diminish mawade fasidah (infected 
material) and rutubate raddia (morbid matter), even to stop their further production.

Mujaffifat (desiccants) are indicated in quruhe naqiyya (non-infected ulcer), while akkal (corrosive) drugs are for quruhe afina (infected ulcer) like zaaj (Alum), hartal (Arsenic disulphate), chuna (calcium carbonate) and tutiya (copper sulphate). ${ }^{44}$

Consider the temperament of the body, temperament of the humor accumulated and temperament of organ involved during treatment. ${ }^{39,41,44}$ Correction of temperament of blood is recommended, if wound healing is delayed due to altered blood (Table 1 and 2).

\section{The treatment of wound is different in different organs}

$1^{\text {st }}$ degree mujaffif adwiya are recommended, if the wound is in moist organ and secretions are scanty. $2^{\text {nd }}$ and $3^{\text {rd }}$ degree mujaffif adwiya are advised, if the wound is in dry organ and secretions are more. Moatadil mizaj mujaffif adwiya are required, if both organ and wound are of normal temperament.

Selection of drugs used for healing of wound are decided based on temperament of body and wound. ${ }^{39,41}$ Mudammile quruh and mulahhim drugs are recommended, if wound is moatadil in rutubat and yabusat. ${ }^{39}$ If body has moist temperament and affected organ is of dry temperament, then there are two situations: use qawi mujaffifat to produce tajfif, if rutubat is more and use zaef mujaffifat, if yabusat is more.

In the treatment of wound, degrees of mujaffifat must be considered; Jalinoos states that, mujaffifat are included in munbate lehem adwiya, as they help in wound healing with desiccation and formation of granulation tissue.

However, severe desiccation is not mandatory with these drugs e.g.; for tajfif shadeed, mujaffifat are used not for the reepithelization but for scab formation. Further, he quoted that qairooti is Munbit-I-Lehem (helps in granulation tissue formation), but it aggravates pus collection, while zangar act as Mani-I-Taqee (deobstruent), but increases the irritation thus causes delay in wound healing. Hence, zangar is mixed with qairooti to counteract with each other. ${ }^{41,44}$ Use qabid (astringent) and lazaj (mucilaginous) drugs after tanqiya quruh for wound healing e.g. gile makhtoom. ${ }^{41}$ Wounds in fleshy mass require extra care as compared to other organs; even wounds having continuous secretions are more dangerous.

If wound and inflammation occur simultaneously; it is necessary to first treat inflammation, as it delayed the wound healing. ${ }^{39}$

\section{Specific measures}

- $\quad$ Treat the cause (Izaslae sabab). 27,28,30,36
- Tanqiya badan with fasde basleeq and use of mushilat. ${ }^{28,30,32-34}$

Use of habis, qabid, mujaffif, mulahhim and mudammile quruh adwiya is recommended for ulcers of internal organs, which usually heals late if associated with inflammation. ${ }^{39}$ Moreover, use of these drugs with honey are advised, as honey is considered best for quruh batina. $^{41}$

In gynecological diseases, maqami kharji tadabir are more beneficial than dakhli tadabir. Hence, apart from internal drugs, local application of drugs is recommended like use of habis (haemostatic) and qabid (astringent) drugs, in the form of humool or farzaja or huqna, and murakhkhi (relaxant) drugs are contraindicated. . $^{27,28,30,33,34,43}$

Use of mulayyin ashiya, musakkin adwiya followed by adwiya mudammila, if ulcer is due to inflammation. ${ }^{27,28}$ Local application of drugs is beneficial, if ulcer is due to trauma. ${ }^{36}$

Use murakkabat of mugharri, qabid and mukhaddir adwiya (Table 3$){ }^{27}$

\section{Treatment (Ilaj)}

Dietotherapy (Ilaj bil ghiza)

Pharmacotherapy (Ilaj bil dawa)

Table 1: Diet allowed and restricted.

\begin{tabular}{|c|c|}
\hline Diet allowed & Diet restricted \\
\hline $\begin{array}{l}\text { Light and nutritious diet (to } \\
\text { provide strength to the patient) } \\
\text { like shorba gosht bakri, chapati, } \\
\text { khichdi moong daal, milk, fruits } \\
\text { and vegetables (palak, khurfa, } \\
\text { kaddu) }\end{array}$ & $\begin{array}{l}\text { Spicy }{ }^{32,36} \text { and oily } \\
\text { food Jaggery. }\end{array}$ \\
\hline
\end{tabular}

Table 2: Food items to keep cervix healthy.

\begin{tabular}{|ll|}
\hline Food factors & Food items \\
Vitamin C & $\begin{array}{l}\text { Papaya, kiwi, pepper, orange, } \\
\text { broccoli, brussels, sprouts, grape } \\
\text { fruit, straw berries }\end{array}$ \\
\hline Sel47
\end{tabular}


Table 3: Drugs indicated with their forms of administration.

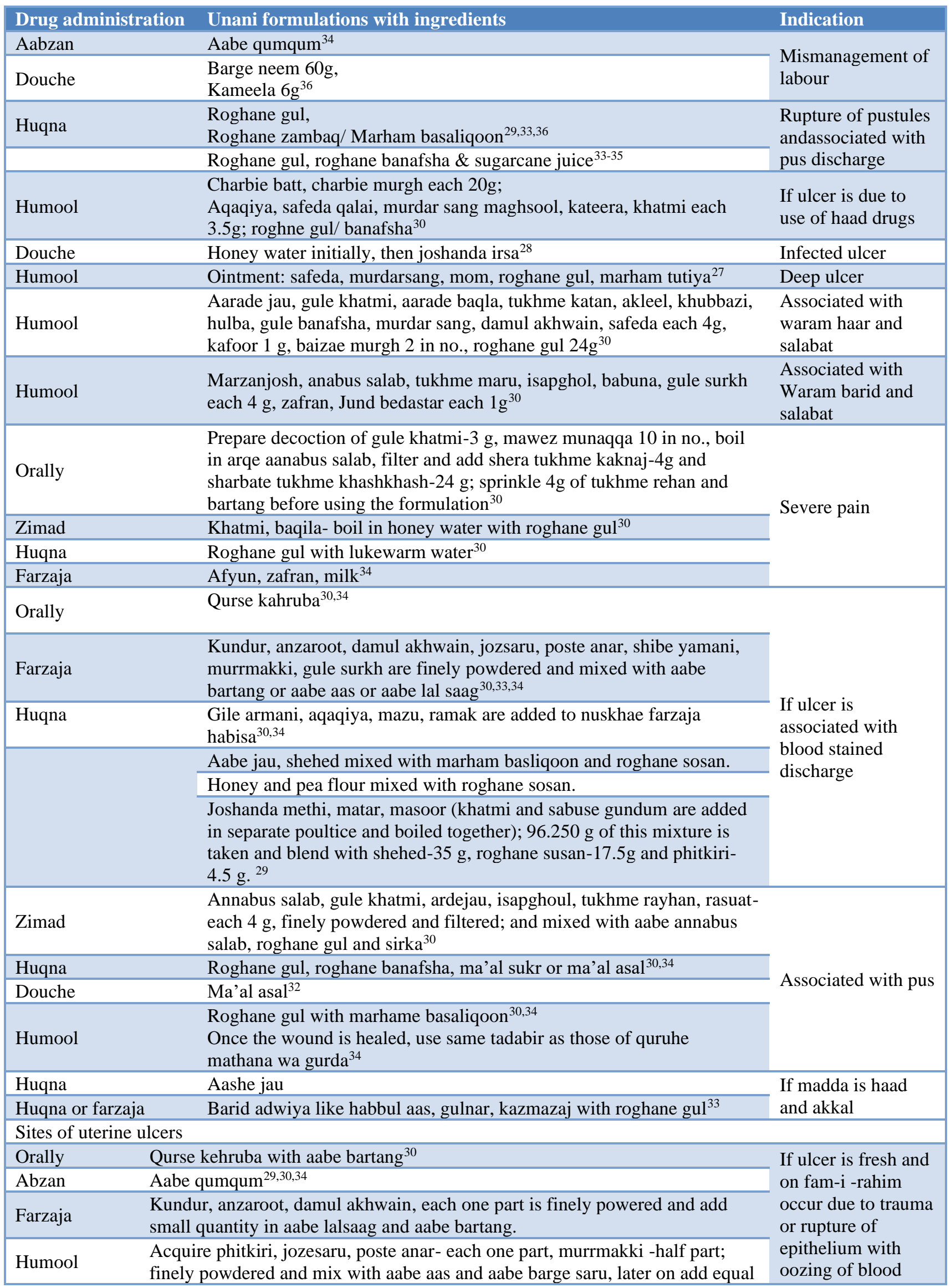




\begin{tabular}{|c|c|c|}
\hline \multicolumn{2}{|c|}{ Drug administration Unani formulations with ingredients } & \multirow{2}{*}{$\begin{array}{l}\text { Indication } \\
\text { from the wound }\end{array}$} \\
\hline & \multirow{2}{*}{$\begin{array}{l}\text { quantity of poste } \text { anar }^{29} \\
\text { loabe isapghoul, tukhme khatmi, gule maru -each } 7 \mathrm{~g} \text {, roghane gul-12 g, } \\
\text { aqaqia, gulnar, shakhe gauzan sokhta, kaghaz sokhta, post baize murgh sokhta, } \\
\text { noful kohna sokhta, damul akhwain - each } 3.5 \mathrm{~g} \text { mixed in aabe bartang and } \\
\text { aabe qumqum }\end{array}$} & \\
\hline Douche & & \\
\hline Huqna & $\begin{array}{l}\text { Aabe aas, aabe shakhe noorista, gulab, aabe bartang, aabe lalsaag -each one } \\
\text { part, acquire } 96.250 \mathrm{~g} \text { of this mixture and insert safoof gile armani, aqaqiya, } \\
\text { ramak, mazu, usara lahiyya al-tees -each } 3.5 \mathrm{~g} \text { and sprinkle joz buwa- } 1.75 \mathrm{~g}^{29}\end{array}$ & \\
\hline Orally & Qurse kehruba with aabe bartang. & \multirow{2}{*}{$\begin{array}{l}\text { Ulcer is on qa'a al } \\
\text { rahim }\end{array}$} \\
\hline Locally & $\begin{array}{l}\text { Gile armani, aqaqiya, mazu, ramak and aabe qumqum in the form of huqna } \\
\text { with nuskha farzajae habisa }{ }^{30,33,34}\end{array}$ & \\
\hline \multicolumn{3}{|c|}{ Treatment according to stages of wound healing } \\
\hline \multicolumn{3}{|c|}{ In initial stage of wound } \\
\hline & $\begin{array}{l}\text { Apply qairooti prepared from murr, safeda, anzaroot, mom and roghane gul } \\
\text { with zangar }{ }^{28}\end{array}$ & Purulent ulcer \\
\hline \multicolumn{3}{|c|}{ Once the wound starts healing } \\
\hline Humool & \multicolumn{2}{|c|}{$\begin{array}{l}\text { Apply qairooti prepared from tootiya maghsool (copper sulphate)-2 part, aqleemiyae fazly, safeda, } \\
\text { anzaroot- each one part with mom and roghane } \text { gul }^{28}\end{array}$} \\
\hline Fateela & \multicolumn{2}{|c|}{$\begin{array}{l}\text { Sibr zard } 7 \mathrm{~g} \text {, sangebasari maghsool, murdarsang, gulnar, geru each } 2 \mathrm{~g} \text {, kundur } 0.5 \mathrm{~g} \text {, post kaddu } \\
\text { talkh sokhta } 1 \mathrm{~g} \text {; finely powdered similar to surma and add aabe kishneez sabz, use two fateeley per } \\
\text { vaginum daily }{ }^{30,33}\end{array}$} \\
\hline Shayaf & \multicolumn{2}{|c|}{$\begin{array}{l}\text { Initially use shaffa of honey to clean the wound, then apply shaffa of mazu for healing of wound; }{ }^{30,33} \\
\text { finally use shaffa of zard chob and roghane gao or }{ }^{30} \text { roghane zard for complete elimination of } \\
\text { inflammation as well as wound. }\end{array}$} \\
\hline Humool & \multicolumn{2}{|c|}{$\begin{array}{l}\text { Decoction: Usarae hina or safoof barg hina or javitri or butter or extract of anar tursh cooked with its } \\
\text { bark and pure honey. }\end{array}$} \\
\hline Aabzan & \multicolumn{2}{|l|}{ Decoction of habbul aas ${ }^{33}$} \\
\hline Huqna & \multicolumn{2}{|l|}{ Roghane bahi ${ }^{33}$} \\
\hline \multicolumn{3}{|c|}{ For cleaning and healing of quruh al-rahim: } \\
\hline Humool & \multicolumn{2}{|c|}{$\begin{array}{l}\text { Prepare marham from maghz tukhm kaddu biryan, maghz tukhm tarbooz biryan (each } 4 \mathrm{~g} \text { ), damul } \\
\text { akhwain, murdarsang, gulnar grinded in sirka, tootiya maghsool, barge hina, post kaddu sokhta (each } \\
1 \mathrm{~g}) \text {, safedi qalai }(2 \mathrm{~g}) \text {; finely powdered and mix mom safed } 2 \mathrm{~g} \text { and roghane gul } 12 \mathrm{~g}^{30}\end{array}$} \\
\hline \multicolumn{3}{|c|}{ Marham of murdar sang, safeda, gulnar, mom and roghane gul. ${ }^{51}$} \\
\hline & \multicolumn{2}{|c|}{$\begin{array}{l}\text { Rasaut, murdar sang, kaat safed, mazu sabz, sangejarahat; all in equal quantity, finely powdered and } \\
\text { mix safedi baizae murgh. }\end{array}$} \\
\hline & \multicolumn{2}{|l|}{ Marham basliqoon (zaft, rateenaj each $84 \mathrm{~g}$, behroza $18 \mathrm{~g}$ with roghan) } \\
\hline & \multicolumn{2}{|c|}{$\begin{array}{l}\text { Marham dakhliyun (roghane zaitoon kohna } 144 \mathrm{~g} \text {, murdarsang } 72 \mathrm{~g} \text {, tukhme khatmi, tukhme maru, } \\
\text { tukhme katan, isapghoul, methi each } 24 \mathrm{~g} \text { : acquire luab of all these drugs and finely add powdered } \\
\text { murdar sang with roghane gul). } \\
\text { Murdar sang, geru, sange jarahat each } 1 \mathrm{~g} \text {, finely powdered and use with marham kafoori } 24 \mathrm{~g}^{36}\end{array}$} \\
\hline
\end{tabular}

\section{Regimenal Therapy (Ilaj Bil Tadbeer)}

\section{General advice}

Adequate rest, avoid contact with heat and abstain from sexual intercourse. ${ }^{36}$ Use diet according to mizaj. ${ }^{28}$

\section{Tadabeer recommended}

Fasd (venesection), talyin (laxation) and ishal (purgation) to prevent insababe rutubat in quruh apart from other benefits. $^{52}$
Takmeedat, nutulaat, zimadat, atlia, aabzan, bukhoor, maqami malish, pichkari, humool, shayaf, farzaja, amale kaiyy etc. ${ }^{38}$

Fasd is recommended apart from intake of heavy diet, if wound is infected and associated with Kathrat-I-Fudlat; more intake of liquid diet is advised, if the wound is non infected due to ghalba yabusat. ${ }^{39}$

Humool and farzaja are specially recommended for maqami zakhm and jaryane dam. ${ }^{43}$ 
Table 4: Evidence based medicines for cervical ectopy.

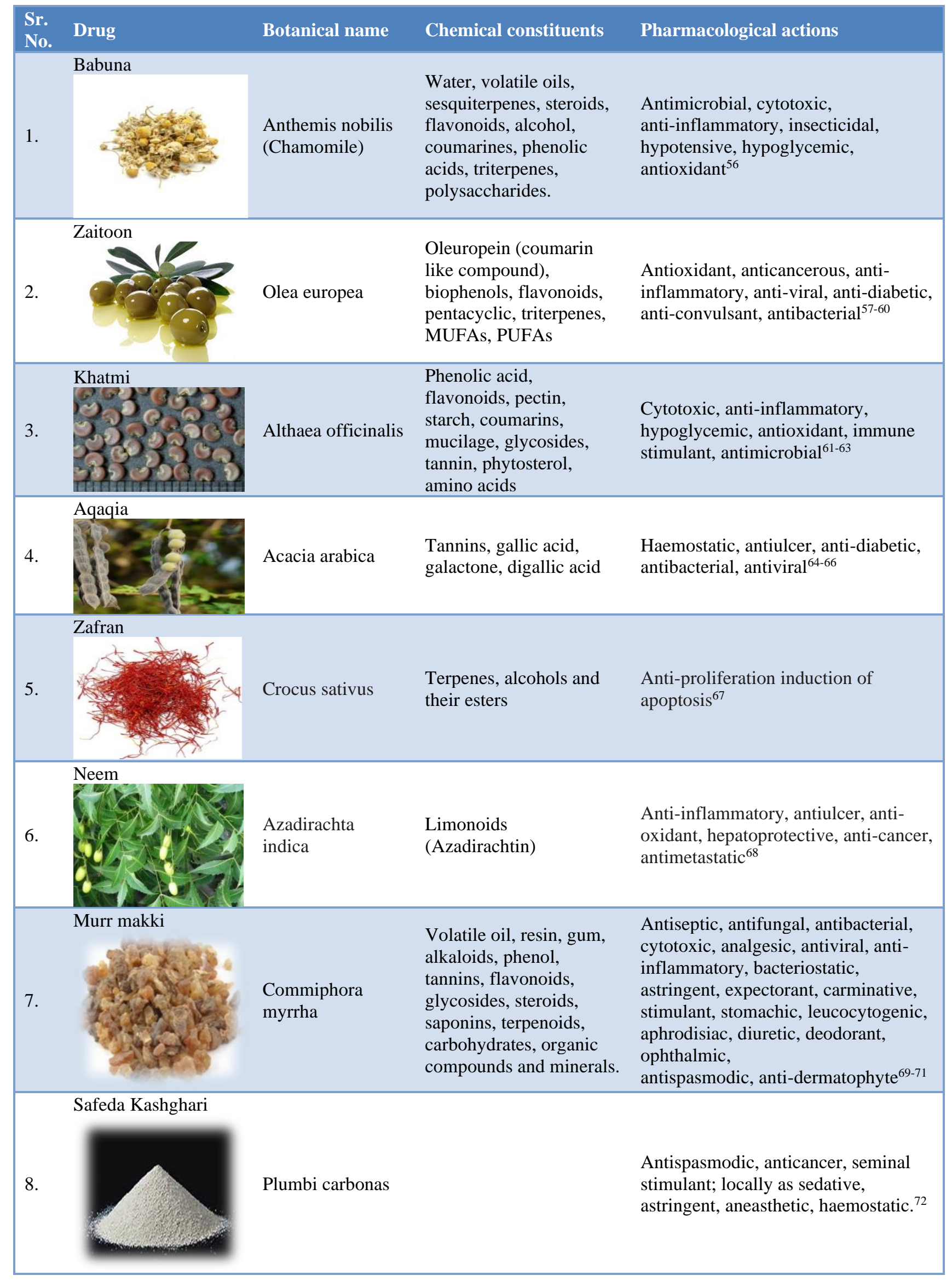







Farzaja and huqna are more beneficial than mulayinat, especially in amraze rahim. ${ }^{30}$

Amale kaiyy bil naar (cauterization) is recommended, if the drugs fail to heal the ulcer. ${ }^{44}$

\section{Tadabeer contraindicated}

Hammam is contraindicated in quruh, as it drains mawad towards the wound, particularly in darjae ibtida and tadhayyad..$^{39,40,52}$

\section{Amal-I-Kaiyy (cauterization)}

Kaiyy is an arabic word which means to cauterize. It is extracted from Unani word Kaiein meaning to burn. Amal-i-Kaiyy is a procedure in which caustic substance; red hot metal rod, electric current, fire etc. are used to burn the flesh in order to dry the excessive fluid, to stop bleeding, to remove the putrefied flesh etc.

The oldest reference of cauterization was found in surgical papyrus in $1600 \mathrm{BC}$ for the treatment of ulcer and tumors. This remedy is considered to have har-yabis effect, thus most effective for the diseases caused by mizaj-i-barid-ratab.53 It is considered as best treatment option not only for tanqiya badan, but for mujaffif rutubat also, if medicine are not effective to cure it. ${ }^{5,44,62}$

Types of cauterization: Amale kaiyy is of two types:

- Kaiyy bil naar (cauterization with fire), where the tissues are burned with fire.

- Kaiyy bil adwiya (cauterization with corrosive drugs), where hawamize kaviya (escharotic acids) and borqiyaat (salts) are used for burning, which leads to the formation of blisters. ${ }^{41}$

Kaiyy bil naar is preferred over kaiyy bil adwiya as fire does not involve the adjacent organs and has no harmful effects.

Ibn Sina recommended that gold metal should be used for cauterization. Razi, with the reference of Jalinoos, suggested that the best metal for cauterization is pure gold because no bulla formation at cauterization site, and even if it forms get cured soon. ${ }^{55}$ Zahrawi has a different view about the selection of metal for cauterization.

He recommends iron as the best metal for it on the basis of following points.

- It is very difficult to assess the approximate temperature of gold even if it becomes red on heating.

- Gold metal get cool soon in comparison to iron as its consistency is less than iron.

- Gold is soft in consistency; thus, it bends or breaks due to the pressure in comparison to iron.
- Iron has a quality to strengthen the overall organs of the body. ${ }^{53,54}$

\section{Gynecological indications}

Uterus: sui mizaj barid ratab sada or maddi, infertility, amenorrhea, painful menses, alteration in menstrual blood flow etc. ${ }^{54,55}$

\section{Amal-I-Kaiyy Jamdi (cold cauterization)}

This is similar to cryo cautery. It is mainly used for cervical ectopy and usually performed in patients having excessive vaginal discharge and also indicated in bleeding, chronic wounds, warts etc. Here, the application of any substance such as liquid nitrogen, carbon dioxide or a very cold instrument is used for the destruction of tissues by freezing. As the temperature is kept at $-800 \mathrm{C}$, hence it has to be performed carefully. ${ }^{53}$

\section{Advantages of cauterization}

Prevents the spread of infection to other healthy organs, dissolves mawade fasida, eliminates leheme fasida (corrupt flesh), which fails to soften with medicines, arrests jiryan-ud-dam, to treat a non-healing ulcer, and for tajfif-i-quruh. ${ }^{41,54}$

\section{DISCUSSION}

Cervical ectopy is one of the commonest gynecological condition seen in OPD's, in women of reproductive age group. Although it is benign, but may be troublesome due to its chronicity and nature of recurrence. In conventional medicine, surgery in the form of cryocautery or electrocautery is the only treatment option for it. While in USM, Various drugs are available which can be used as topical application in the form of douche, pessary, etc., exhibiting anti-microbial, anti-inflammatory, antioxidant, anti-cancer, anti-ulcer, analgesic, wound healing activities due to the presence of flavonoids, saponins carbohydrates, alkaloids etc; which are considered as the active principle of anti-ulcer activity (Table 4).

Hence, these Unani drugs must be used in day to day clinical practice due to their beneficial effects since ancient times as mentioned in the literature. Further, randomized controlled trials on large sample size are recommended to proof the efficacy and safety of these Unani drugs in the management of cervical ectopy.

Funding: No funding sources

Conflict of interest: None declared

Ethical approval: Not required

\section{REFERENCES}

1. Jindal M, Kaur S, Sharma S, Gupta KB, Pandotra P, Bhavna. What is better: cryocautery or electrocautery 
for cervical erosion?. Int J Reprod Contracept Obstet Gynecol. 2014;3(3):715-9.

2. Bangal VB, Patil NA, Gavhane SP, Shinde KK. Colposcopy guided management of cervical erosion in rural population. SJAMS. 2014;2(1C):261-5.

3. Rupapara AV, Donga SB, Dei LP. Review of clinical studies on cervical erosion (Garbhashaya GrivamukhagataVrana). IAMJ. 2015;3(4):1290-6.

4. Meena P, Gaurav P. Role of kasharakarma in recurrent cervical erosion: a case study. JAHM. 2014;2(6):60-3.

5. Bright PL, Turner AN, Morrison CS, Wong EL, Kwok C, Yacobson I, et al. Hormonal contraception and area of cervical ectopy: a longitudinal assessment. Elsevier-Contracept. 2011;84:512-9.

6. Kamini D, Meena P, Dhiman KS. Kampillakadi ghrita in garbhashaya greeva gata vrana (Cervical erosion). IJRAP. 2012;3(2):203-8.

7. Eleuterio L, Giraldo PC, Goncalves AKS, Amaral RLG, Linhares LM. Uterine cervical ectopy during reproductive age: cytological and microbiological findings. Diagnos Cytopathol. 2014;42(5):401-3.

8. Shivanna BS, Shivanna L, Kulkarni P. Comparative study of efficacy of cryosurgery and albothyl solution in the management of cervical erosion in a rural hospital. IOSR-JDMS. 2014;13(9):106-8.

9. Hua X, Zeng Y, Zhang R, Wang H, Diao J, Zhang P. Using platelet rich plasma for the treatment of symptomatic cervical ectopy. IJGO. 2012;119:26-9.

10. Wright KO, Mohammed AS, Olatunji OS, Kuyinu YA. Cervical ectropion and intrauterine contraceptive device (IUCD): a five-year retrospective study of family planning clients of a tertiary health institution in Lagos Nigeria. BMC. 2014;7(946):2-6.

11. Machado LC, Dalmaso ASW, Carvalho HB. Evidence of benefits from treating cervical ectopy: literature review. Sau Paulo Med J. 2008;126(2):1329.

12. Venkatesh KK, Susan C. Assessing the relationship between cervical ectopy and HIV susceptibility: Implications for HIV prevention in women. Am J Reprod Immunol. 2013;69(1):68-73.

13. Patil P, Sharma P. Colposcopic evaluation of cervical erosion in symptomatic women. Int $\mathbf{J}$ Reprod Contracept Obstet Gynecol. 2017;6(6):2207-11.

14. Monroy OL, Aguilar C, Lizano M, Talonia FC, Cruz RM, Zavaleta LR. Prevalance of human papillomavirus genotypes, and mucosal IgA antiviral responses in women with cervical ectopy. J Clin Virol. 2010;47:43-8.

15. Yang K, Liu Y, Wu T, Roberts H, Li J, Zhang, et al. Microwave therapy for cervical ectropion. Cochrane Database Syst Rev. 2008;1:CD006227.

16. Sharma P, Sharma S. A clinical study to evaluate efficacy of Snuhi Kshara and Dhatakyadi Tail Pichu in the management of Karnini Yonivyapad w.s.r to cervical erosion .WJPR. 2015;4(10):1258-65.

17. Moscicki AN, Ma Y, Holland C, Vermund SH. Cervical ectopy in adolescent girls with and without human immunodeficiency virus infection. J Infect Dis. 2001;183:865-70.

18. Kupchak I, Genyk N. Combination therapy of uterine cervical ectopy in young nulliparous women. Pharma Innovat J. 2015;4(8):41-4.

19. Kahn JA, Hillard PJ. Cervical cytology screening and management of abnormal cytology in adolescent girls. J Pediatr Adolesc Gynecol. 2003;16:167-71.

20. Gautam A, Rajan S, Rajan S, Sharma E. A clinical study of Kusthadi Varti in Karnini Yonivyapada w.s.r to cervical erosion. Int $\mathbf{J}$ Current Res. 2017;9(12):62140-3.

21. Matiluko AF. Cervical ectropion. Part 2: assessment of symptomatic women. TUGSH. 2009:16-22.

22. Sanchez A, Rivera A, Castillo A, Ortiz O. Cervical erosion as a result of infectious vaginitis. Euro J Exp Bio. 2012;2(5):1659-63.

23. Cekmez Y, Sanlikan F, Gocmen A, Vural A, Turkmen SB. Is cryotherapy friend or foe for symptomatic cervical ectopy?. Med Princ Prac. 2016;25:8-11.

24. Kumar P, Malhotra N. Jeffcoate's Principles of gynaecology. $7^{\text {th }}$ ed. New Delhi: Jaypee Brothers Medical Pubishers (P) Ltd; 2008:410-411.

25. Gupta P, Sharma S. Clinical evaluation of the efficacy of Kashara Karma with Apamarga Kashara and Jyatyadi taila pichu in the management of cervical erosion (Karnini yonivyavada). WJCPMT. 2015;1(3):43-9.

26. Mitchell L, King $M$, Brillhart $H$, Goldstein A. Cervical ectropion may be a cause of desquamative inflammatory vaginitis. a case report. Sexual Med. 2017;5(3):e212-14.

27. Razi ABZ, Al Hawi Fil Tib. Vol IX. New Delhi: CCRUM; 2001:10,12,24,25,36,41,42,47,50,53.

28. Sina I. Al Qanoon Fil Tib (Urdu trans. by Kantoori GH). New Delhi: Ejaz Publication House. 2010:4478.

29. Majusi AIA. Kamilus Sana (Urdu trans. by Kantoori. GH). New Delhi: Idarae Kitabul Shifa. 2010;437:496-97.

30. Al Akseer KA. (Urdu trans. by Kabeeruddin). $1^{\text {st }}$ ed. New Delhi: Idarae Kitabul Shifa; 2011:450:788-790.

31. Qamari MH, Mana G. $1^{\text {st }}$ ed. New Delhi: Markazi Council Barai Tehqeeq Tibbe Unani; 2008:414-415.

32. Razi ABZ. Kitabul Mansoori. $1^{\text {st }}$ ed. New Delhi: CCRUM; 1991:388.

33. Jilani G. Makhzanul Ilaj. Vol I. $1^{\text {st }}$ ed. New Delhi: Idarae Kitabul Shifa; 2005:667-668.

34. Arzani A, Tibbe A. (Trans. by H. Mohd Hussain). Deoband: Faisal publications; YNM: 597-99.

35. Chandpuri K. Mojiz Al Qanoon. $3^{\text {rd }}$ ed. New Delhi: CCRUM; 1998:396.

36. Kabiruddin HM. Bayaze Kabeer. Vol I. Hyderabad: Hikmat Book Depot; 1935:201-202.

37. Iqbal SMF, Parray SA, Wadud A, Jahan N. Concept of gastric ulcer (Qarhe medah) in Unani system of medicine: a review. IJIPBS. 2012;1(1):133-43. 
38. Jamil SS, Ahmad HZ, Siddiqui KM, Hannan A, Ahmad B, Quddusi N, et al. Standard Unani medical terminology. New Delhi: CCRUM; 2012:306.

39. Baghdadi IH. Kitabul Mukhtarat Fil Tibb. Vol I. New Delhi: CCRUM; 2007:296-297.

40. Rushd I. Kitabul Kulliyat. $2^{\text {nd }}$ ed. New Delhi: CCRUM; 1987:79-81,84,85,286,304,310.

41. Hamdani KH. Usoole Tibb. $3^{\text {rd }}$ ed. New Delhi: Qaumi Council Baraye Farogh Urdu Zuban; 2006:169-83,196,203-04,493-94,508-11.

42. Baghdadi IH. Kitabul Mukhtarat Fil Tibb. Vol IV. New Delhi: CCRUM; 2007:46-47.

43. Qarshi MH. Jamiul-Hikmat. Vol I and II. $1^{\text {st }}$ ed. New Delhi: Idarae Kitabul Shifa; 2011:1102.

44. Kabiruddin H. Tarjuma wa Shareh Kulliyate Qanoon.Vol I and II. Lahore: Sheikh Mohd Basheer and sons; YNM; 1976:368-70.

45. Sina I. Al-Qanun Fil-Tibb (English trans. of critical arabic text). Part 1. New Delhi: Jamia Hamdard Printing Press; 1988:176:375.

46. Hosseini A, Ghorbani A. Cancer therapy with phytochemicals: evidence from clinical studies. Avicenna J Phytomed. 2015;5(2):84-97.

47. Merina N, Chandra KJ, Jibon K. Medicinal plants with potential anticancer activities: a review. IRJP. 2012;3(6):1-5.

48. Foods with anticancerous effects. Available at: URL:www.betternutrition.com/features-dept/cervical -dysplasia-cervix-cancer-treatment-prevention. Accessed on $23^{\text {rd }}$ March 2018.

49. Mosby TT, Cosgrove M, Sarkardei S, Akal P, Kaina B. Nutrition in adult and childhood cancer: Role of carcinogens and anticarcinogens. Anticancer Res. 2012;32:4171-92.

50. Fahad T, Shameem I. An evidence based approach to the management of cervical cancer in Unani system of medicine: a review. JPP. 2018;7(2):2536-44.

51. Tabari R. Firdausul hikmat (Urdu trans. by Shah MA). New Delhi: Idarae Kitabul Shifa; 2010:257258.

52. Rahman RU, Misbahi FR, Shamsi Y. Management of first and second degree haemorrhoids with combined oral and topical Unani formulations. IJAHM. 2014;4(5):1557-68.

53. Nayab M. Conceptual description of Amal-i-Kaiyy (Cauterization): an overview. Int J Adv Sci Res. 2017;2(1):42-5.

54. Maseehi IQ. Kitabul Umda Fil Jarahat. Vol II. New Delhi: CCRUM; YNM; 1986:169,180-82.

55. Zahravi AQ. Jarahiyate Zahravi (Urdu trans. by Hakim Nisar Ahmad Alwi Kakori). $1^{\text {st }}$ ed. New Delhi: CCRUM; 2012:3-5,25.

56. Al-Snafi AE. Medical importance of Anthemis nobilis (Chamaemelum nobile): a review. AJPST. 2016:6(2):89-95.

57. Fares R, Bazzi S, Serine E, Baydoun, Roula M, Massih A. The antioxidant and anti-proliferative activity of the lebanese Olea europaea extract.Plant foods Hum Nutr. 2011;66:58-63.
58. Hashmi MA, Khan A, Hanif M, Farooq U, Perveen S. Traditional uses, phytochemistry and pharmacology of Olea europaea (Olive). Evid Based Complement Alternat Med. 2015:1-25.

59. Asif M. Biological significance of seed oil and polyphenolic of Olea europaea. IJHM. 2013;1(1):2841.

60. Boss A, Bishop KS, Marlow G, Barnett MPG, Ferguson LR. Evidence to support the anti-cancer effect of Olive leaf extract and future directions. Nutrient. 2016;8:2-22.

61. Rezaei M, Dadgar Z, Zadeh AL, Namin SAM, Pakzad I, Davodian E. Evaluation of the antibacterial activity of the Althaea officinalis L. leaf extract and its wound healing potency in the rat model of excision wound creation. AJP. 2015;5(2):105-12.

62. Shah SMA, Akhtar N, Akram M, Shah PA, Saeed T, Ahmed K, et al. Pharmacological activity of Althaea officinalis L. JMPR. 2011;5(24):5662-6.

63. Sadighara P, Gharibi S, Jafari AM, Khaniki GJ, Salari S. The antioxidant and flavonoid contents of Althaea officinalis L. flowers based on their color. AJP. 2012;2(3):113-7.

64. Bhatnagar M, Parwani L, Sharma V, Ganguli J, Bhatnagar A. Hemostatic, antibacterial biopolymers from Acacia arabica (Lam.) Willd. And Moringa oleifera (Lam.) as potential wound dressing materials. IJEB. 2013;51:804-10.

65. Hegazy GA, Alnoury AM, Gad HG. The role of Acacia Arabica extract as an antidiabetic, antihyperlipidemic, and antioxidant in streptozotocin-induced diabetic rats. Saudi Med J. 2013;34(7):727-33.

66. Sundaram R, Mitra SK. Antioxidant activity of ethyl acetate soluble fraction of Acacia arabica bark in rats. IJP. 2007;39(1):33-8.

67. Wang SJ, Zheng CJ, Peng C, Zhang H, Jiang YP, Han T, et al. Plants and cervical cancer-An overview. Expert Opin Investig Drugs. 2013;22(9):2-24.

68. Zaid H, Saad B. Cancer treatment in the ArabIslamic medicine: Integration of tradition with modern experimental trails. JAMIAH. 2010;14:1339.

69. Shulan SU, Wang T, Chen T, Duan J, Yu L, Tang Y. Cytotoxicity activity of extracts and compounds from Commiphora myrrha resin against human gynecologic cancer cells. JMPR. 2011;5(8):1382-9.

70. Adam ME, Selim SA. Antimicrobial activity of essential oil and methanol extract from Commiphora molmol (Engl.) resin. Int J Curr Microbiol App Sci. 2013;2(12):1-6.

71. Fahad T, Shameem I. Phytochemical and therapeutic potentials of murr makki (Commiphora myrrha): a review. IJAR. 2018;8(9):2249-555X.

72. Rahman RU, Misbahi FR, Shamsi Y. Management of first and second degree haemorrhoids with combined oral and topical Unani formulations. IJAHM. 2014;4(5):1557-68.

73. Gur CS, Onbasilar I, Atilla P, Genc R, Cakar N, Gurhan ID, et al. In vitro growth stimulatory and in 
vivo wound healing studies on cycloartane-type saponins of Astragalus genus. J Ethnopharmacol. 2011;134:844-50.

74. Li X, Qu L, Dong Y, Han L, Liu E, Fang S, et al. A review of recent research progress on the Astragalus genus. Molecules. 2014;19:18850-80.

75. Mohebitabar S, Shirazi M, Bioos S, Rahimi R, Malekshahi F, Nejatbakhsh F. Therapeutic efficacy of rose oil: A comprehensive review of clinical evidence. AJP. 2017;7(3):206-13.

76. Tavirani MR, Fayazfar S, Keshel SH, Razaee MB, Azodi MZ, Tavirani MR, et al. Effect of essential oil of Rosa Damascena on human colon cancer cell line SW742. Gastroenterol Hepatol Bed Bench. 2013;6(1):25-31.

77. Anonymous. The Unani pharmacopoeia of India. Vol I. Part II. $1^{\text {st }}$ ed. New Delhi: AYUSH; 2009:106-107.

78. Venkatesa S, Prabu R, Arulvel M, Ishwarya TR, Arunkumar SC. Cytotoxic potential of extracts of Punica granatum fruit and bark against hela cell lines. Int J Pharmacy Res. 2013;2(1):1-14.

79. Haque N, Sofi G, Ali W, Rashid M, Itrat M. A comprehensive review of phytochemical and pharmacological profile of Anar (Punica granatum Linn): A heaven's fruit. J Ayu Herb Med. 2015;1(1):22-6.

80. Alipanah H, Bigdeli MR, Esmaeli MA. Inhibitory effect of Viola odorata extract on tumor growth and metastasis in 4T1 breast cancer model. Iranian J Pharma Res. 2018;17(1):276-91.

81. Asheesh K, Suresh C, Meenakshi P. A brief knowledge of Banafsha (Viola odorata Linn.) and other Viola species. IJAPR. 2017;5(4):73-8.
82. Siddiqui MZ. Boswellia serrata, a potential antiinflammatory agent: an overview. IJPS. 2011;73(3):255-61.

83. Ismail SM, Aluru S, Sambasivarao KRS, Matcha B. Antimicrobial activity of frankincense of Boswellia serrata. Int $\mathrm{J}$ Curr Micobiol App Sci. 2014;3(10):1095-101.

84. Ali A, Hamiduddin, Zaigham M. Shibb-e- yamani (Alum) a unique drug and its utilization in Unani medicine: a physicochemical and pharmacological review. Int J Res Ayurveda Pharm. 2017;8(2):17-22.

85. Mendoza S, Noa M, Valle M, Mendoza N, Mas R. Ameliorating effects of D-002, a mixture of beeswax alcohols on monosodium iodoacetate-induced osteoarthritis in rats. Int $\mathrm{J}$ Pharm Sci Rev Res. 2013;19(1):10-5.

86. Kacaniova M, Vukovic N, Chlebo R, Haschik P, Rovna K, Cubon J, et al. The antimicrobial activity of honey, bee pollen loads and bees wax from Slovakia. Arch Biol Sci. 2012;64(3):927-34.

87. Ahmed S, Sulaiman SA, Baig AA, Ibrahim M, Liaqat $S$, Fatima $S$, et al. Honey as a potential natural antioxidant medicine: an insight into its molecular mechanisms of action. Hindawi. 2018:1-20.

88. Hadagali MD, Chua LS. The anti-inflammatory and wound healing properties of honey. Eur Food Res Technol. 2014;239:1003-14.

Cite this article as: Fahad T, Shameem I. Concept of cervical ectopy/Quruhal Rahim in Unani system of medicine: a review. Int J Reprod Contracept Obstet Gynecol 2020;9:3519-29. 